\title{
Copyright Reform and Business Model Innovation: Regulatory Propaganda at German Music Industry Conferences
}

\author{
Leonhard Dobusch
}

Elke Schüßler

Freie Universität Berlin

School of Business \& Economics - Department of Management ${ }^{1},^{2}$

\section{DRAFT FEBRUARY 2013}

Final version forthcoming in Technological Forecasting and Social

\section{Change}

Quote as: Dobusch, L./Schüßler, E. (2014): Copyright reform and business model innovation:

Regulatory propaganda at German music industry conferences. Technological Forecasting and Social Change 83: 24-39.

\footnotetext{
${ }^{1}$ Both authors have contributed equally to the development of this paper. Author names are therefore in alphabetical order.

2 Acknowledgements: previous versions of this paper have been presented at the Fourth Villa Vigoni Conference on Economic Sociology and Political Economy 2010, and at the Free Culture Research Conference 2010. We are indebted to Jörg Sydow, Sigrid Quack and Lauri Wessel for their detailed feedback. We would also like to thank the guest editor, Vincent Mangematin, and three anonymous reviewers for their helpful suggestions for developing this paper.
} 


\title{
Copyright Reform and Business Model Innovation: Regulatory Propaganda at German Music Industry Conferences
}

\begin{abstract}
Inspired by new digital technologies, diverse actors in cultural and creative industries propagate conflicting visions of how to adequately innovate - or rather preserve and strictly enforce - copyright-related business models, which has resulted in substantial amounts of regulatory uncertainty. Looking at a decade of regulatory discourse at industry events in the popular music industry in Germany, we investigate how these actors make sense of and strategically shape this uncertainty in the process of industry transformation. Our longitudinal argumentative discourse analysis reveals cycles of regulatory propaganda of two discourse coalitions that do not engage in debate, but aim to find support for competing business models among regulators and the public. Organizing, canceling, and participating in industry events are discursive strategies used effectively to transport their claims by both industry lobbyists and challenging actors, but industry incumbents are failing to use these sites for testing out and introducing new business models. We conclude that regulatory struggles, not least at industry events, mediate between disruptive technologies and business model innovation.
\end{abstract}

\section{Keywords}

copyright; industry events; music industry; regulatory discourse; regulatory propaganda 


\section{Introduction}

Recent technological developments, above all the Internet and file sharing software, have created uncertainty about whether extant copyright regulation and according business models will be sustainable in the future, particularly in the music industry $[5,24,42]$. During the 1990s, copyright-related regulatory struggles were fought out predominantly in transnational arenas such as the World Trade Organization (WTO) or the World Intellectual Property Organization (WIPO). Subsequently, debates and lobbying efforts shifted to national arenas, as the transnational treaties had to be built into national law. European countries are hereby expected to follow the EU Copyright Directive, passed by the European Union in 2001 as a step towards implementing the WIPO copyright treaty. Today, more than ten years later, even large European countries such as Germany have not implemented all parts of the Directive and heated debates about copyright reforms continue.

While the lobbying efforts of major corporations and industry associations for a stronger protection of copyrights on a transnational level are already well understood (e.g. $[25,41,51,66])$, we know much less about the national regulatory struggles that followed. This is an important gap in both regulation and business studies, as the outcome of these national regulatory processes is indispensible for the development of viable business models in the music industry specifically (e.g. [6]) and in the so-called copyright industries (e.g. [18,81]) more broadly. In order to capture the political dimension of business model innovation that is largely missing in research on web-based business models (e.g. [87]), we define business model as a new "system of interdependent activities that transcends the focal firm and spans its boundaries" [92], but explicitly include the societal level of organizational fields and accompanying regulatory issues [43] in this definition as well. This allows us to consider the free provision of cultural goods [56] pursued by an increasing number of actors not necessarily from the music industry, but from the wider field of copyright regulation as an 
alternative business model in our analysis and provides a bridge to recent studies on social or institutional innovations accompanying the technological ones in processes of industry transformation (e.g. $[28,52])$.

Empirically, we follow Hajer's [36] argumentative discourse analytical approach and study the discourse coalitions forming in the German popular music industry around the issue of copyright regulation between 2001 and 2010, the decade after the passing of the EU Copyright Directive.We investigate how different actors make sense of regulation alternatives in the light of old and potential new business models at industry events. Events such as conferences have recently been introduced as shared discursive spaces in organizational fields where central and peripheral field actors can come together and shape regulatory structures [39]. Convening at industry events may thus be a viable strategy for industry actors facing regulatory uncertainty in processes of industry transformation. In order to elaborate on our understanding of the regulatory and political dimension of business model innovation, we study the discoursive struggles among industry incumbents and other field actors unfolding at German music industry events and ask: How do different actors in a transforming industry address regulatory uncertainty in processes of business model innovation?

We find, first, that regulatory debate is taking place increasingly at music industry fairs and festivals, venues that have not traditionally hosted conference sections. New events and event formats have been founded to provide discursive spaces for addressing regulatory uncertainty regarding copyright. Second, we find an ebbing and a growing intensity of regulatory debates depending on the perceived success of copyright-related business models over time. The dominant public narrative throughout our ten-year examination period has revolved around the threat posed by Internet file sharing and the call for regulation to protect existing business models, manifested in the lobbying efforts of core music industry actors to legally protect Digital Rights Management (DRM) technologies against circumenvention [7,79]. As a 
reaction to these developments, a growing number of organizations and individuals have developed a counter-narrative, in which they depict industry incumbents as part of a problem rather than the solution to any copyright reform efforts. Without the backing of strong corporate support, this challenger coalition consisted (at least initially) mostly of startup companies, small online-only music distributors ("netlabels", see [31]), non-profit organizations such as Creative Commons [21], dissident or avant-garde artists and, later in the process, the newly founded pirate parties. ${ }^{3}$ By advocating copyright reform and new business models that were compatible with new digital technologies such as peer-to-peer file sharing, these actors resemble social-movement-like market activists, or "market rebels" [73]. Rather than engaging in regulatory conversations [10] and synthesizing new business models, however, the competing incumbent and challenging actor groups direct their claims mainly at the public and regulators. We thus observe cycles of conflicting regulatory propaganda fueled by recurring industry crises within the phases of industry evolution (e.g. $[84,70])$. The outcome of these regulatory debates may well be one of those factors that mediate the passing from one stage in the industry life-cycle to the next.

The remainder of this paper is organized as follows: we introduce our theoretical perspective on business models, regulation, and the discursive spaces provided by industry events. Then we explain in more detail our research setting, the popular music industry in Germany, and outline our methodological approach, methods of data collection, and data analysis. We present our findings on overall changes in the music event landscape as well as the discourse coalitions forming over time before discussing our results on what we call cycles of regulatory propaganda and business model innovation.

\footnotetext{
${ }^{3}$ The German Pirate Party is one of the strongest, holding seats in several municipal and state parliaments. See http:/governancexborders.com/2011/09/19/boarding-berlin-the-pirate-party-triumph-in-the-german-capital-faq/ [accessed November 29, 2011]
} 


\section{Theoretical Perspectives: Business Models, Regulation, and the Role of Discursive Spaces}

Over the last two decades, the difficulties of copyright regulation in accounting for new technological developments and enforcing certain parts of copyright such as the right to distribute music online have cast doubt on its functionality. In spite - or even because - of its repeated revisions (see, e.g. [54]), the accuracy of copyright as a regulatory basis for business models has been contested, leading to regulatory uncertainty among actors in copyrightrelated industries such as music, film, and publishing. We will now first outline our discursive perspective on the link between business model innovation and regulatory uncertainty, and then discuss the role of discourse and industry events in this context.

\subsection{Business Model Innovation and Regulatory Uncertainty: A Discursive Perspective}

In ideal terms, a central feature of regulation is the reduction of uncertainty for the actors within a given field by making the actions of others more predictable [14]. In an industry context, regulation is therefore both restricting and enabling, in that it prescribes a set of behaviours against which business models and paths of innovation can be developed. Consequently, uncertainty resulting from the absence, complexity, or ambiguity of regulation, i.e. regulatory uncertainty, is mostly considered to be problematic for corporate investement decisions [71,44]. In the field of environmental regulation, Engau and Hoffmann [26] even state that "regulatory uncertainty considerably constrains firms and can adversely affect their profitability [12] because the continuous preparation for, and the adjustment to, uncertain regulations absorb firm resources". From the perspective of corporate actors, regulatory uncertainty may therefore be defined as the "inability to predict the future state of the regulatory environment" [45]. 
As opposed to this predominantly negative view of regulatory uncertainty from an investment perspective, others point to the fact that uncertainty also leaves room for innovation. Jauch and Kraft [47], for example, argue that an uncertain environment might help actors to be more proactive and innovative $[60,58,30]$. In the history of information and communication technologies, business models based upon new technologies such as radio or cable television typically created and exploited regulatory uncertainty; often, innovative business models were in conflict with extant regulatory structures and became legalized only retroactively (see e.g. [88]). In the light of these examples, regulatory uncertainty cannot - and should not - be avoided altogether, but is a necessary by-product of innovation processes because it opens up the scope of future action within an industry.

While existing business model research has recognized the link between business model innovation, technology and experimentation (e.g. [19]), the role of regulatory uncertainty in these processes has rarely been explicitly integrated. Sabatier et al. [75], for instance, focus on technological uncertainty and argue that in mature industries such as the drug industry, disruptive business models only emerge when new technologies evolve and the associated uncertainty decreases. Sainio and Puumalainen [76] examine technological and market uncertainties in firms' interpretations of disruptive technologies, but do not discuss how these firms act upon these uncertainties in developing new business models. In this paper, we suggest that whether regulatory uncertainty eventually leads to business model innovation is contingent upon how this uncertainty is coped with in a given field.

In order to capture this aspect, we propose to draw on Black's [10] concept of regulatory conversations, by which she conceptualizes regulation as a communicative process "involving the sustained and focused attempt to alter the behaviour of others according to identified purposes $[\ldots$, i.e.] the intentional, goal-directed, problem-solving attempts at ordering undertaken by both state and non-state actors." Such a discursive perspective on regulation is 
important for understanding the development of new business models, especially in the copyright industries, because it pays attention to the political-cultural processes unfolding among industry incumbents and challengers seeking to define new and legitimate practices $[29,42]$. These practices reach beyond mere value propositions in terms of business profits, including the level of social and societal values as well [90]. Most existing research on the transformation of these industries, including the music industry, has either focused on macrolevel institutional or technological developments (e.g. [23]) or on strategic responses and behavior patterns on the micro-level of firms and individuals (e.g. $[67,64,46]$ ), but has neglected the level of interactions among different public and private actors in the wider organizational and regulatory field (see [2] for an exception). Although regulation does play a role in several studies on industry evolution (e.g. [86,20]), the role of regulatory uncertainty in obstructing or stimulating business model innovation has rarely been considered. As an exception, Meijer and colleagues [60] explicitly study actors' perceptions of different sources of uncertainty to understand innovation decisions better, and find that uncertainty seems to block some but inspire others to achieve a transition.

\subsection{Industry Events as Discursive Spaces for Regulatory Conversations}

Regulatory conversations take place in processes of rule-setting between regulating bodies and practitioners in a field, for example in the form of expert opionions or lobbying activites [82]. In private regulation initiatives via standards [16,13], regulatory conversations often take place solely among practitioners. Regulatory conversations may either clarify or obscure the interpretation of, and guide the implementation of different types of regulation. The processes of rule-setting, rule interpretation, and rule implementation are typically cases of "distributed agency, not only in terms of actors but also in terms of activities" [72].

Recent work on the evolution of organizational, institutional, technological, or professional fields has recognized the importance of field configuring events (FCEs) [53,62] in facilitating 
such distributed regulatory processes. At FCEs, actors from diverse backgrounds encounter each other and ideas proliferate, allowing for intended and unintended processes of field configuration [53]. In their study of a transnational regulatory process facilitated by a series of United Nations conferences, Hardy and Maguire [39] draw on Hajer's [36] concept of discursive spaces, defined as physical or virtual spaces in which actors discuss, debate, and dispute issues important to them. They argue that FCEs provide multiple overlapping discursive spaces that allow both powerful and peripheral actors to drive or hinder change in transnational regulations through the production, distribution and consumption of texts that can flow between the discursive spaces. FCEs, therefore, not only provide opportunities for face-to-face dialogue that concentrates dominant frames and story lines both temporally and locally $[8,77]$, but also create places "where new things can be said and new social structures envisioned" [39].

In the context of a changing industry under regulatory uncertainty, industry events such as trade fairs or conferences are likely to act as FCEs, because the discursive interactions taking place at such events allow for collective sensemaking [67], but also allow participants to strategically propagate their accounts while challenging those of competing actors [59]. In our research context, this means that participants may use industry events as platforms to exploit regulatory uncertainty by discursively positioning their distinct visions of the music industry's future business models. These accounts are then reflected in related media coverage [3] external discursive spaces addressed via communications circulated beyond the event itself [39]. Although regulatory conversations are conducted via different channels and at multiple locales, they are thus likely to unfold at industry events and their surrounding discursive spaces.

\section{Research Setting and Methodology}


The popular music industry is one of the core copyright industries, defined as "those industries whose primary purpose is to create, produce, distribute or exhibit copyright materials." [78]. Of all the different copyright industries, the music industry was the first to experience substantive threats to a major part of its established business model - selling CDs on the consumer market for music - when digitization and Internet file-sharing of MP3compressed music emerged during the late 1990s [35,64,83,91]. As shown by recent developments in the film and publishing industries, here the music industry was more of a front-runner than an exception in facing challenges in the course of digitization [27,57], which makes it a particularly interesting field for studying the link between regulatory processes and business model innovation.

The rationale for selecting the German music industry as a case for investigating how regulatory uncertainty is addressed at industry events is twofold. First, Germany is the third largest consumer market, with strong subsidiaries or - as in the case of EMI - even headquarters of international music industry incumbents. Second, Germany has a highly dynamic and internationally recognized music industry event landscape, culminating in the recent deconstruction of the Popkomm, traditionally one of the three largest music industry fairs worldwide, and the parallel emergence of several challenging events. Our study addresses both the macro-level development of the event landscape in the German popular music industry between 2001 and 2010, in order to account for dynamics in the event-related discursive spaces that are provided, and the media discourse triggered by four selected events in those years. We chose this ten-year period as being critical for the copyright discourse in Germany, as copyright became a major issue for national legislatures in Europe only after the passing of the EU Copyright Directive in 2001.

Our analysis largely follows Hajer's [36,37] method of an argumentative discourse analysis. Hajer defines discourse as "an ensemble of ideas, concepts, and categories through which 
meaning is given to phenomena" and argues that successful discourse may be solidified into an institution, a process called "discourse institutionalization" [36] (see also [34]). Prevailing in conflict-ridden discursive processes are those social constructs shared by the wider group of people: the dominant discourse coalition. Any discourse coalition is "related to practices in the context in which actors employ story lines and (re)produce and transform particular discourses" [37]. These story lines are the medium of political action, as they suggest certain positions and practices, and criticize others. A discourse coalition thus includes the following elements: a set of story lines, the actors that utter these story lines, and the practices that conform to these story lines [36]. Importantly, while paying attention to strategic action and power, the discourse coalition approach also illuminates the unintended (re-)production of a discursive bias by different actors who do not necessarily share deep values or orchestrate their activities, but cluster around specific story lines held together by the "discursive affinity" of their arguments [36]. As meanings are produced interactively, an argumentative discourse analysis is based on the detailed examination of accounts of these interactions [37].

In conducting a discourse analysis, Hajer [37] proposes examining statements that are often conveyed in the form of a narrative, i.e. as story lines with a beginning, a mid point, and an end. Often, people use short cues rather than telling the whole story, which is the reason why people who do not actually share the same understanding may still form a joint discourse coalition, assuming that the same narrative is shared by others. In this paper we apply this approach in a more focused way and pre-select certain sites of argumentative exchange by focusing on industry events in the German music industry, because, as we have argued before, they are sites particularly well-suited for presenting positions and exchanging ideas. In Hajer's terms and in line with Hardy and Maguire's [39] concept of discursive spaces, events are sites where story lines are constructed and discourse coalitions formed and maintained.

\subsection{Data Collection}


In order to understand when the regulation of copyright was picked up as an issue and by whom, we first constructed a chronology of all events with a conference or convention section in the music industry between 2001 and 2010. We searched through the archive of the main music industry magazine in Germany, the Musikwoche, featuring an extensive weekly event calendar to identify all industry events in a year. First, we searched for several German synonyms for the term "conference", as well as for the English terms "conference" and "camp", and included all our findings into an event database. This initial search yielded 77 results. We consolidated this list by first exluding all events from other countries (e.g. the Amsterdam Dance Event) and from other industries such as the Frankfurt book fair. We also excluded mere music festivals that did not have at least one official discussion panel, as we did not consider these events to be critical for the formation of discourse coalitions. Second, we looked for additional online information on the remaining events to collect their beginning and end date as well as their mission and content. On this basis we further reduced our initial list and deleted international events that only took place once in Germany (e.g. the WOMEX world music fair). We also merged events that were listed as separate, but actually belonged to one event, such as the International MatchMaking Event that was a regular part of the Popkomm between 2005 and 2007. Our final list comprised 25 events. $^{5}$

From this basis, we zoomed into a selection of four highly significant event series to gain insights into core issues, debates, and actor groups that have dominated the copyright and associated industry transformation discourse in the German popular music industry since 2001: the Popkomm, the c/o pop/C'n'B, the Reeperbahn Festival/Campus, and the all2gethernow $(\mathrm{a} 2 \mathrm{n})$. The four events are theoretically relevant [89] because they all stand for alternative conceptions about the dominant and most promising business models in the music

\footnotetext{
4 “Konferenz" (conference), "Messe" (fair), "Kongress" (congress)

5 We checked how biased the Musikwoche, as the main industry magazine, was by searching through an alternative German news source, gulli.com, a webportal reporting about music production and distribution models compatible with peer-to-peer file-sharing. We could only confirm one missing event there, the "Cologne Commons", which is why we accepted this bias as an acceptable limitation.
} 
industry. The Popkomm is the biggest event that took place regularly throughout our selected time period and stands for the mainstream music industry dominated by major-labels. A large international industry fair, the Popkomm was attracted away from Cologne by the city of Berlin in 2004. It was canceled in 2009 with reference to illegal downloads ${ }^{6}$ and the resulting revenue loss in the music industry, and has since been trying unsucessfully to recover under the label of Berlin Music Week. The Popkomm-move was countered with the founding of the c/o pop in Cologne in 2004, which established a new conference format, the Create and Business Convention C'n'B, in 2009. The Reeperbahn Festival in Hamburg is a live music festival modeled on the South by Southwest event in Texas; it complemented its original 2006 format with a conference section, the Reeperbahn Campus, in 2009, the year of the Popkomm cancellation. In this year, the all2gethernow was founded as a counter-event in Berlin, using a decidedly different event format from the Popkomm.

These three latter events thus represent alternatives to the Popkomm's exclusive industry focus. While we expect partly overlapping discourse coalitions and story lines regarding copyright regulation and related business models at the Popkomm and c/o pop/C'n'B, we expect differences at the latter two events, because the all2gethernow is more targeted towards the digital scene, whereas the Reeperbahn Festival/Campus is geared towards live music rather than the recorded music business. These four events are repeatedly compared and jointly discussed in the industry press ${ }^{7}$, including online polls among readers asking which event to attend, so we consider these events representative of the main lines of debate in the German music industry and comparable regarding their visibility and discursive impact, which is also evidenced by the number of conference sessions and visitors at these events. The Popkomm, as formerly the world's third largest music industry fair, attracted about

\footnotetext{
${ }^{6}$ See Handelsblatt, June 19, 2009, http://www.handelsblatt.com/unternehmen/it-medien/popkomm-wegenpiraterie-protest-abgesagt;2375028 [accessed: March 28, 2010]

${ }^{7}$ Unlike other event series such as the Pop-Up in Leipzig or the popforum in Mannheim, which have a similar format.
} 
15,000 visitors for over 800 exhibits from over 50 countries. The c/o pop's C'n'B Convention has been attended on average by about 1000 visitors from over 20 countries, engaging in about 60 different conference, networking, or panel sessions offered during a two-day period. The Reeperbahn Campus now features more than 100 different program items and attracts about 1500 visitors. Finally, the first a2n edition comprised more than 100 sessions and was attended by over 1000 visitors.

We took media reporting of these events as a proxy for their role in regulatory conversations and conducted a comprehensive media search as a basis for our argumentative discourse analysis. Overall, our aim was to identify compatible and incompatible story lines, associate them with certain actor groups (not) participating at these events, and link them to field-level practices in terms of the business models or regulatory initiatives pursued. To establish our database, we searched both regional (Berliner Zeitung, Rheinische Post Düsseldorf, Hamburger Abendblatt) and national newspapers (Süddeutsche Zeitung, Frankfurter Allgemeine Zeitung) as well as the main music industry magazine Musikwoche for references to each of the three events in the 10 years from 2001 to 2010 . We collapsed all the articles into one file for each medium and event (e.g. Popkomm-Berliner Zeitung, Popkomm-FAZ etc.). If articles came up several times because all three events were mentioned in one article, we included only one instance of the respective passage in our analysis to avoid duplicates.

Additionally, at least one of the authors attended the $c / o$ pop/C'n'B between 2008 and 2010, the Popkomm in 2010, and the all2gethernow in 2009 and 2010. We recorded many panel discussions, collected leaflets and other documents distributed at the event, and engaged in informal conversations with the participants and exhibitors. We also conducted sixteen interviews with event organizers for background information on each event. The interviews lasted between 30 and 90 minutes approximately and were attended by at least one researcher. We selected the core organizing team including the founders of each event as interviewees to 
get a broad range of perspectives. All the interviews were semistructured and guided by an interview protocol comprising five elements: a reflection of what happened in 2009, the development history of each event, the events' vision for the future of the industry, the organizing team and participants over time, and the role of specific topics such as digital distribution. All the interviews were recorded and transcribed. An overview of the collected data can be found in Table 1 .

\begin{tabular}{|c|c|c|c|c|}
\hline & clo pop/C'n'B & all2gethernow & Popkomm & Reeperbahn \\
\hline \multirow[t]{6}{*}{ Interviews } & I 1: Founder/ CEO & I 5: Founder/CEO & $\begin{array}{l}\text { I 9: Founder/ } \\
\text { Former CEO }\end{array}$ & $\begin{array}{l}\text { I 15: Founder/ } \\
\text { CEO }\end{array}$ \\
\hline & $\begin{array}{l}\text { I } 2: \text { Head of } \\
\text { Convention }\end{array}$ & I 6: Head of Event & $\begin{array}{l}\text { I 10: Head of } \\
\text { Conference }\end{array}$ & $\begin{array}{l}\text { I 16: Head of } \\
\text { Program }\end{array}$ \\
\hline & $\begin{array}{l}\text { I 3: Head of } \\
\text { Strategy }\end{array}$ & $\begin{array}{l}\text { I 7: Member of } \\
\text { Organizing Team I }\end{array}$ & $\begin{array}{l}\text { I 11: Manager } \\
\text { Exhibition }\end{array}$ & \\
\hline & $\begin{array}{l}\text { I } 4: \text { Head of } \\
\text { Finance }\end{array}$ & $\begin{array}{l}\text { I 8: Member of } \\
\text { Organizing Team II }\end{array}$ & $\begin{array}{l}\text { I 12: Manager } \\
\text { Marketing }\end{array}$ & \\
\hline & & & I 13: Manager Event I & \\
\hline & & & I 14: Manager Event II & \\
\hline Observations & $\begin{array}{l}2009,2010 \\
100 \text { formal } \\
\text { participant } \\
\text { interviews* }\end{array}$ & $\begin{array}{l}2009,2010 \\
\text { Informal conversations } \\
\text { with participants }\end{array}$ & $\begin{array}{l}2010 \\
\text { Informal conversations } \\
\text { with participants }\end{array}$ & - \\
\hline Documents & $\begin{array}{l}\text { Programs } 2005 * *_{-} \\
2010\end{array}$ & Program 2009-2010 & Programs 2003-2010 & $\begin{array}{l}\text { Programs 2009- } \\
2010_{* * *}\end{array}$ \\
\hline $\begin{array}{l}\text { Press } \\
\text { (between 2001- } \\
\text { 2010) }\end{array}$ & \multicolumn{4}{|c|}{$\begin{array}{l}\text { Daily Press: } \\
\text { National Newspapers: Süddeutsche Zeitung, Frankfurter Allgemeine Zeitung } \\
\text { Regional Newspapers:. Berliner Zeitung (Berlin), Rheinische Post Düsseldorf (Cologne), } \\
\text { Hamburger Abendblatt (Hamburg) }\end{array}$} \\
\hline \multicolumn{5}{|c|}{$\begin{array}{l}\text { * These formal interviews were conducted for an evaluation project concerning the C'n'B event format. They } \\
\text { provided us with background information about how participants perceived the new convention compared to the } \\
\text { other events we studied. We have not systematically coded these interviews, however, so we list them here under } \\
\text { observations. } \\
\text { ** c/o pop conference was established in } 2005 \\
* * * \text { Reeperbahn Campus Conference was established in } 2009\end{array}$} \\
\hline
\end{tabular}

\section{Table 1: Database}

\subsection{Data Analysis}

While we used the interview transcripts and participant observations as background information for our analysis, we systematically coded all the media data using the Atlas.ti content analysis software. First, we searched through all the media texts for passages referring 
to the broader theme of "copyright". This search was done manually, as we read through all the texts in order to get a grasp of the material at hand. To ensure similar interpretations, we started to read through and code the same texts separately and then compared our coding results. After having resolved differences in coding, we divided the material for the rest of the coding process, but jointly discussed unclear cases. We cross-checked this coding process by searching for a list of key words related to copyright ${ }^{8}$. We found some additional passages in this way that we had overlooked in the manual search and, if relevant, coded these as well.

We then fine-coded the respective passages with respect to the types of actors making certain statements and the kinds of arguments made. This fine-coding was conducted by one author and then cross-checked by the other. We counted as statements all demands, proposals, criticisms, and decisions referring to copyright issues, following the process of a political claims analysis described by Haunss and Kohlmorgen [40]. Overall, we coded 434 passages that referred to the issue of copyright. These contained 34 different claims and, altogether, 381 instances of claims were reported. Independent of the content, we coded the year of each press article and the event context in which a claim was made. We were thus able to say what type of actor made what claim at which point in time. Aiming to get a better understanding of the structure of the discourse with respect to both copyright regulation and business models, we classified each claim as either "conservative" or "reformist". As can be seen in Table A.1 in the Appendix, we categorized 13 claims as conservative and 15 claims as reformist. Six claims were not typical of any position. Furthermore, we grouped claims into one of three inductively derived alternative business models: the "music as a commodity model" (COM), the "music as a service or promotion tool model" (SPM), and the "music as a public good

\footnotetext{
8 This list of keywords was generated through the initial manual coding process. Search words included: "copyright", "downloads", "legal", "digital rights", "DRM", but also German words such as "Regulierung" (regulation), "Urheber" (author), "Pirat" (pirate), "Eigentum" (ownership), "Werte" (values), "Rechte" (rights).
} 
model" (PGM) (see also Table A.1). These models are described in more detail in the findings section.

\section{Findings: The Copyright Discourse in the German Music Industry}

The presentation of our findings follows the two steps of our analyis, focussing first on the evolution of the overall event landscape and then discussing the regulatory discourse associated with four selected, central events.

\subsection{Event Landscape in the German Music Industry}

We identified 25 different event series that took place in parallel or at different time periods in the German music industry between 2001 and 2010 and that also fulfilled our selection criterion of being a public event hosting some sort of conference where industry-related issues were discussed. Generally, we observed a steady rise in the number of events with conference sections where regulatory issues were discussed from only six in the year 2001 to 20 in the year 2010 (Figure 1). The only event series that ran through the entire time period were the Popkomm, the DJ Meeting, and the Music City Hamburg. Of these, the Popkomm is the only event of international scope addressing the entire popular music industry. The Music City Hamburg, by contrast, is a regional music industry meeting; the DJ Meeting is a fair and conference exclusively targeting the DJ scene. Some events such as the $c /$ pop/C'n'B and the Reeperbahn Festival/Campus are music festivals with a conference section. Others, such as the Popkomm, My Music or the Pop Up are trade fairs with both a festival and a conference section. Finally, some events are predominantely discussion platforms, either dedicated to special issues such as the Green Music Initiative or more general issues such as the Future Music Camp.

The first event that disappeared from the landscape in 2004 was Musik und Maschine in Berlin. Led by Dimitri Hegemann (owner of the Tresor-Club, Berlin) and Jeff Mills (Techno 
DJ, Detroit), it was one of the first events in Germany discussing topics such as copyright and the role of major labels in the music industry. The pop:forum Branchenmeeting, taking place first in Stuttgart, then in Mannheim, ended in 2005, together with the Munich Mobile Music Conference, which was only founded in 2004. The pop:forum was dedicated to debating the future music industry and had Gerd Gebhardt, at that time head of the German Music Industry Association, as its patron. The Mobile Music Conference was only a short event to discuss business models related to mobile phones and music. In 2009, two further event series ended: the relatively small Musikfachtagung organized by the Konrad Adenauer Stiftung (the political foundation of the conservative party CDU) and the Popkomm. The Popkomm reappeared in 2010 under the umbrella of Berlin Music Week. A more detailed view of the evolving event landscape can be seen in Table A.2 in the Appendix.

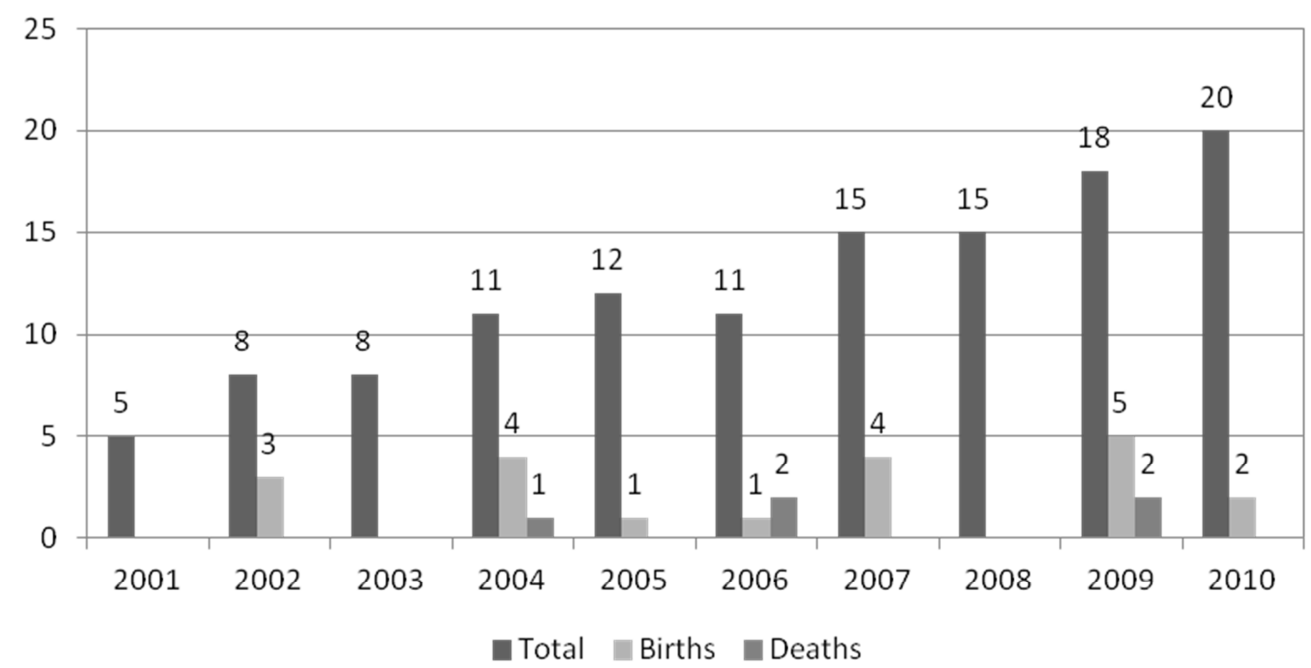

Figure 1: Evolution of the event landscape in the German music industry from 2001 to 2010.

While some events have an openly conservative orientation towards the regulation of copyright, i.e. target the protection of existing business models, others debate entirely different themes such as the integrative role of music in the context of migration policy (Musikfachtagung). In 2009, two events, the Future Music Camp and the all2gethernow, were founded using a barcamp rather than a conference-format to initiate a more open debate about 
the future of the music industry and related copyright regulation. Both events are inherently focused on digital business, but only the all2gethernow is rooted in the open source community.

Looking at the evolution of the event landscape in the German music industry as a whole, the most striking finding is the overall increase in the number of events during a period of perceived industry crisis. The organizers of these events do not necessarily come from the core music industry, but are diverse actors ranging from the telecommunications and IT industries (Mobile Music Conference, Cebit Sounds, all2gethernow) to political foundations (Musikfachtagung), and even to regional politicians (forward2business-Zukunftskongress) and festival organizers seeking to seize the opportunity provided by uncertainty to gain funding and visibility through a new conference section $\left(C^{\prime} n^{\prime} B\right.$, Reeperbahn Campus). The next section tries to capture the dynamics of regulatory claims made by different actors during the past decade in the context of selected events.

\subsection{Discourse on Copyright and Business Models at Industry Events over Time}

When looking at the overall timeline of claims (Figure 2) and the development of concrete claims behind it (Table A.3), we identify three phases with respectively dominant story lines.

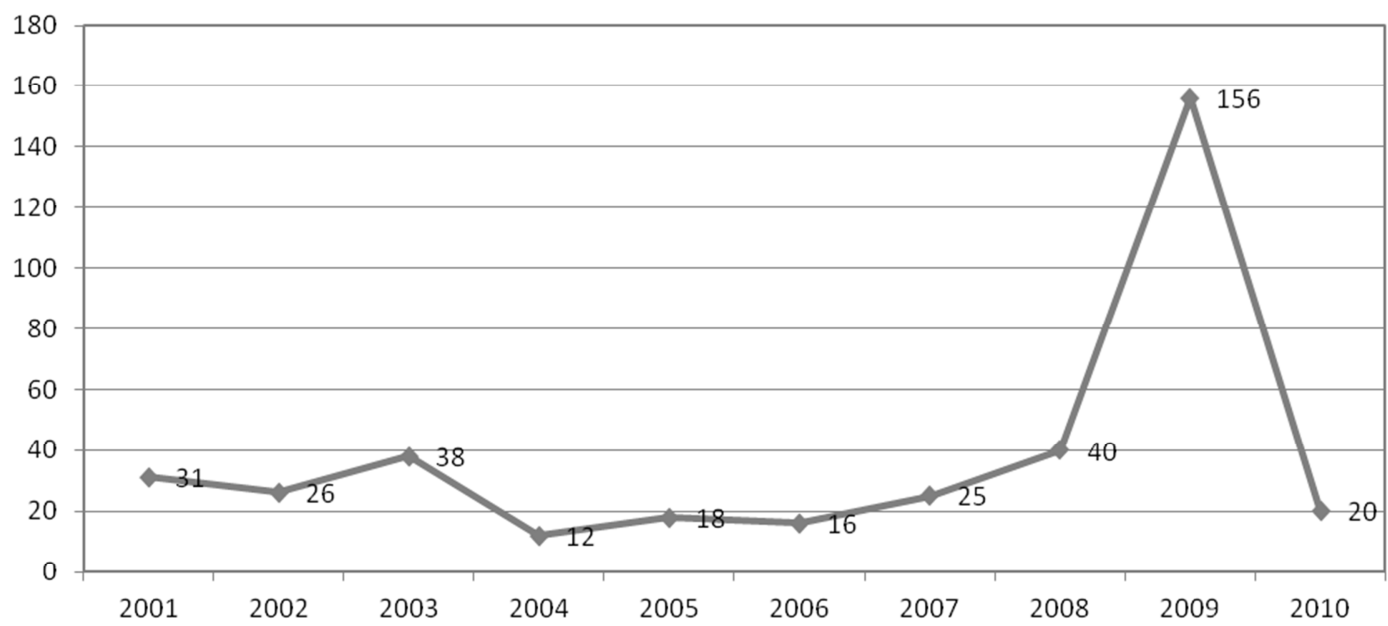

Figure 2: Overall timeline of business model claims between 2001 and 2010. 
In the first period between 2001 and 2003, DRM was debated as a solution to the music industry's crisis, preserving the dominant music-as-a-commodity business model that is based on the strict enforcement of copyright regarding the sale and consumption of recorded music. The precondition to DRM strategies working was the legal protection of DRM technologies against circumenvention, the so-called "anti-circumvention provisions", which had to be implemented on a national level. In Germany, a penality for the circumvention of copy protection measures was introduced into national copyright law in a first copyright reform basket in September 2003, a measure welcomed by industry actors such as major label representatives:

"But now major labels want to strike back. Before long the new copyright law will come into effect, which forbids the circumvention of copy protection of music CDs.” (Hamburger Abendblatt, 2003)

However, in this first period industry incumbents already remained under pressure and we observe a growing number of claims that call for new business models. These new models reconceptualized music as a service or as a promotion tool and were typically made by actors new to the music business and aiming to occupy a niche in the reconfiguring music value chain (e.g. "Microsoft wants to forestall competitor Apple with its new offers in Europe", FAZ 2003).

In the second period, between 2004 and 2007, incumbents began implementing DRM and not many issues were debated at all. The claim that filesharing was causing the industry crisis, prominent in the first phase, as well as the discussion of alternative business models declined. In 2008, a third period started when it became clear that DRM was not the solution to the music industry's problems. Starting with EMI in late 2007, the major labels abandoned DRM strategies one after another. In this period, claims were increasingly voiced that government needs to act, enforcing copyright more strictly: 
"Dieter Gorny [head of the German Music Industry Association] pled for an intensified battle against pirated copies: 'The notion of a bagatelle is deadly!'” (Hamburger Abendblatt, 2008)

This period culminated in the Popkomm cancellation, which was used to again propagate the message that Internet filesharing is illegal and was causing the crisis of the music industry (see also Table 2). Voices more diverse than in the first period grew stronger to counter this claim, arguing that the music industry was failing to innovate and that this was the main reason for its crisis:

"Seipenbusch [then head of the German Pirate Party] attracted attention mainly through statements such as 'the whining cries of the music industry remind us of coachmen after the introduction of the automobile'." (Musikwoche, 2009)

This counter-narrative or alternative story line manifested itself in the foundation of new events, most notably the all2gethernow. But in addition to re-emerging claims for service or promotion business models (e.g. "[M]usic such [...] is only an 'add-on', an instrument for customer loyalty together with other products," FAZ, 2008), the conception of music as a public good that is financed, for instance, with so-called cultural flatrate models was introduced into the debate by new actors such as the Pirate Parties (e.g. "Everything must be permitted, as long as there is no commercial background," MM, 2009). Figure 3 depicts the frequency of claims relating to the different business models over time, and Table A.3 gives coding examples of the three business model categories. 


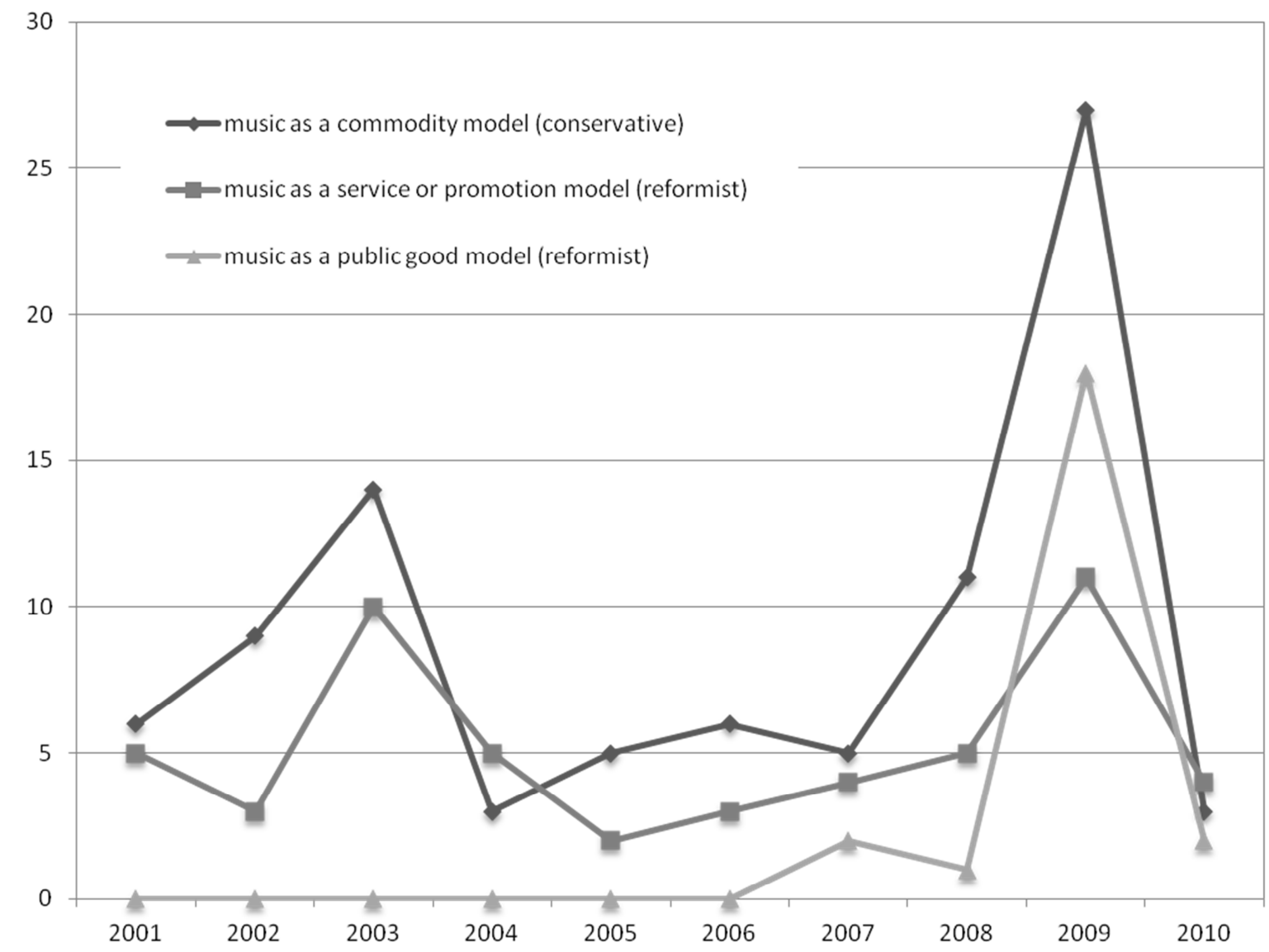

Figure 3: Frequency of claims related to different music industry business models between 2001 and 2010.

When looking at the types of claims made in relation to our four different events, the following picture appears (Figure 4): whereas the all2gethernow, the $c / o$ pop/C'n'B and the Reeperbahn Festival/Campus were represented by more reformist positions, the Popkomm was dominantly associated with conservative claims. It is hereby important to note, however, that both in articles about the clo pop/C'n'B and about the all2gethernow a number of the conservationist positions coded result from references to the Popkomm cancellation and hence were not positions directly voiced at these events. Conservative claims were therefore strongly present in the reporting of all events - which indicates that event organizers cannot necessarily control how their event will be represented in the media. Of the 122 conservative claims made in relation to the Popkomm, 29 were made with reference to its cancellation. 


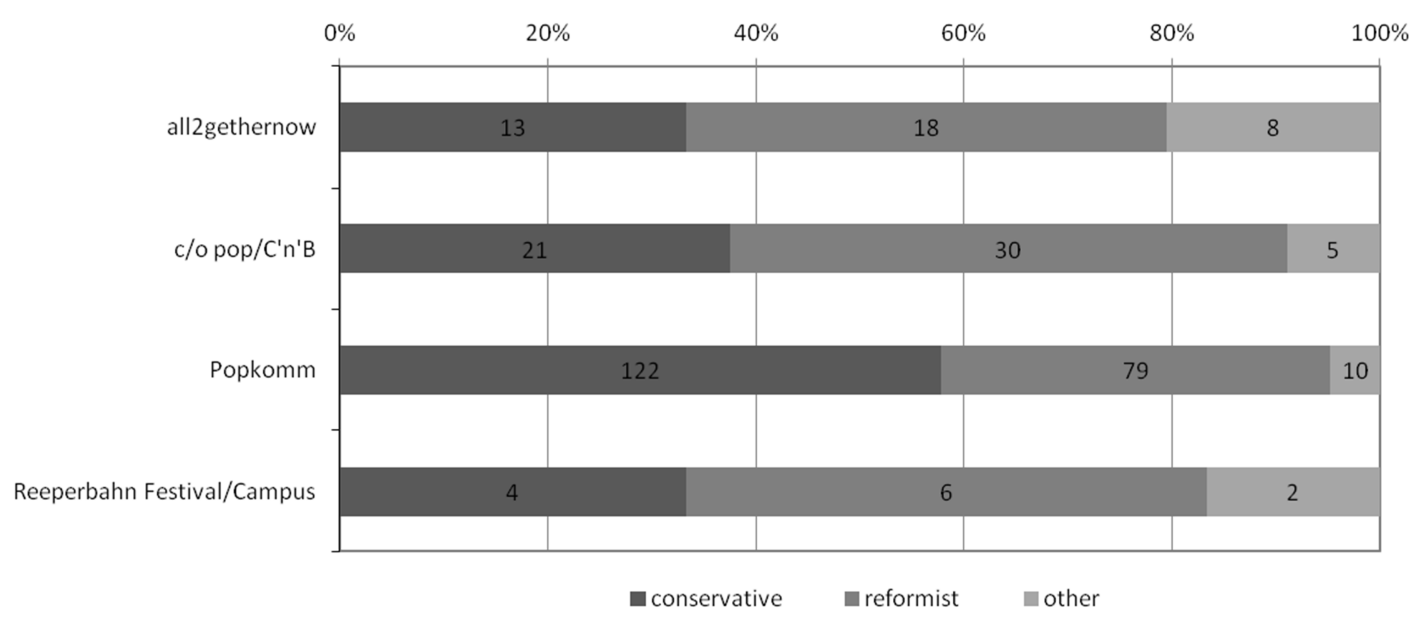

Figure 4: Conservative, reformist and other claims related to the events under study.

The role of the media as a non-neutral arbiter becomes very visible when looking at the actors behind the different claims (Figure 5): media actors not only report on claims, but also make claims themselves as commentators. In our case, media commentators have a strong bias towards reformist positions (ratio of 2 to 1 ), thereby contributing to putting conservative claims by industry actors into a critical perspective.

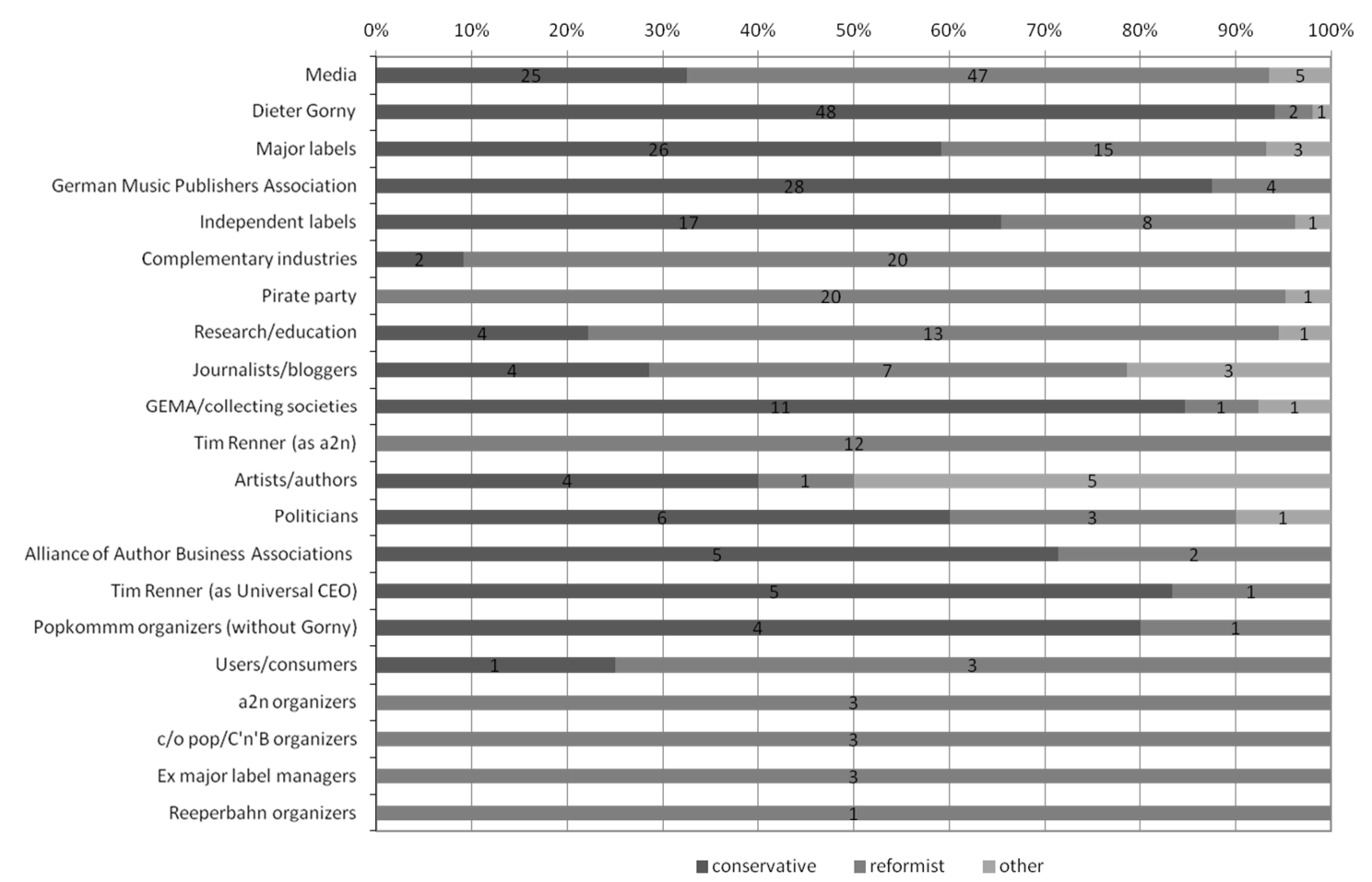

Figure 5: Actors making conservative, reformist and other business model claims. 
Overall, we identified 21 different actor groups. The most dominant actor after media commentators themselves is Dieter Gorny, Popkomm founder and now head of the German Music Industry Association and one of the most prominent lobbyists for the music industry. Gorny accounts for almost a quarter of all claims, not least because he attributed the Popkomm cancellation to Internet piracy. Dieter Gorny is followed by the music industry, i.e. the major labels, the Business Association of German Music Publishers, and indie label representatives. Together, these four actors account for more than half (153 of 381) of the claims overall. Most of the claims of these actors were conservative. This conservative group is followed by a smaller group of actors with mostly reformist claims: complementary industries (comprising the games industry, ISP providers, etc.), the Pirate Party, and various experts such as professors, journalists, and bloggers. Examples of the most prominent claims of each actor group with more than 10 claims can be seen in Table A.4.

Half of the claims attributed to creators such as artists or authors could not be clearly categorized as either conservative or reformist; this reflects the fact that, while generally agreeing with the pro-copyright stance of the industry actors, artists are not content with how industry actors are handling these issues, for example in terms of revenue distribution. The least represented actors are the organizers of the Reeperbahn Festival/Campus. Tim Renner, former Universal Music CEO and now an author, head of a radio station and head of the all2gethernow conference, can be associated with very different kinds of claims depending on which role he had at a given time.

When calculating the mean position of the different actor groups on a conservative-reformist scale (Figure 6), two discourse coalitions can be identified, one at the conservative end of the spectrum consisting of Dieter Gorny (as both former Popkomm founder and head of the German Music Industry Association), the German collecting society GEMA, the industry associations, and Tim Renner as Universal manager. This coalition also includes, in a slightly 
weaker form, the authors/artists and their representative organizations, collectively organized as ADAM (Alliance of German Music-Author Associations) since the 2009 c/o pop/C'n'B event. Furthermore, the major and indie labels, and politicians are positioned on the conservative half of the spectrum, albeit in a weaker form. On the reformist side, there are no actors directly involved in the music industry value chain, but rather the media, different kinds of experts, users and consumers, as well as actors from complementary fields such as the games industry and the event organizers (excluding the Popkomm).

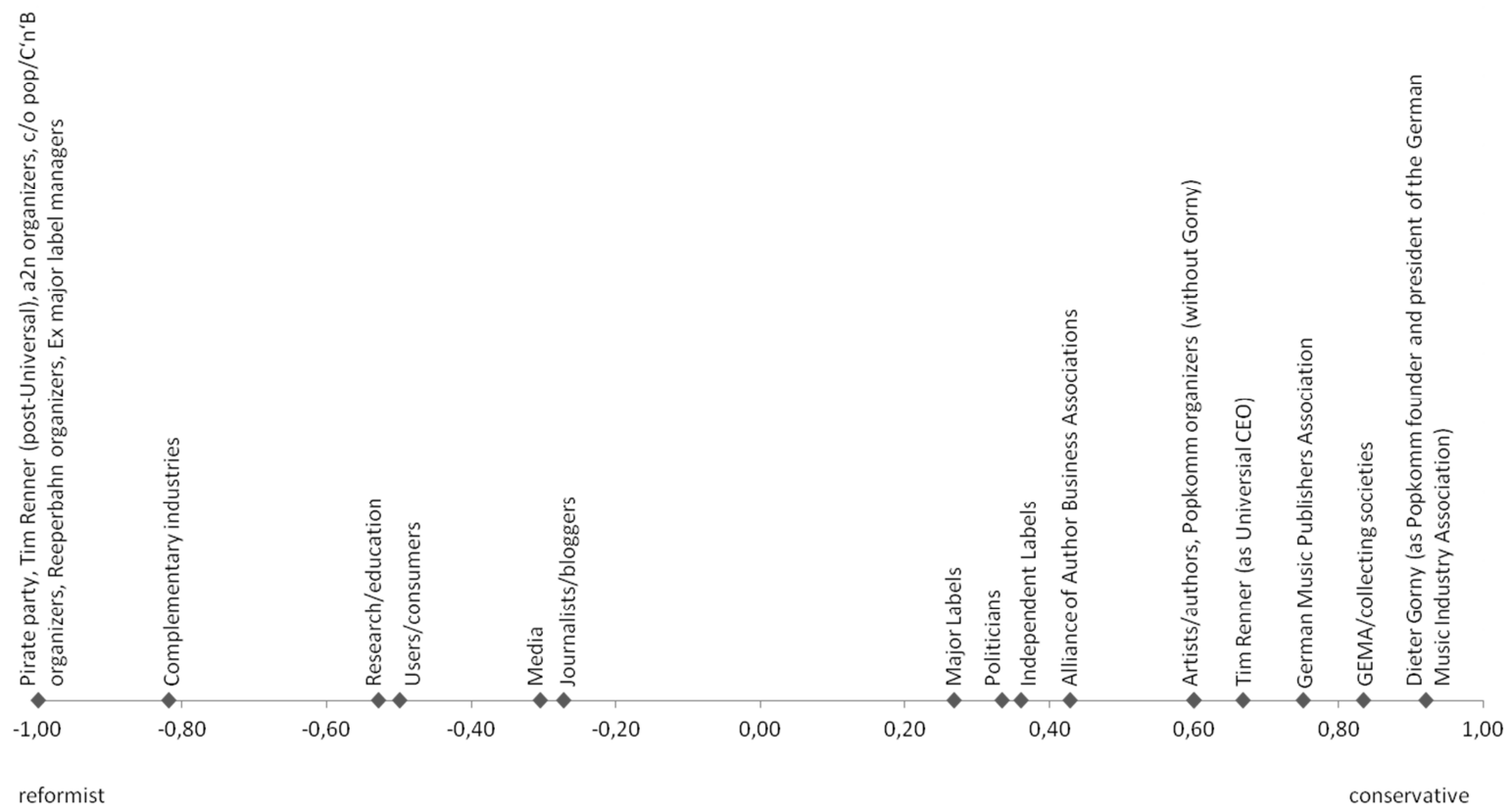

Figure 6: Discourse coalitions in the German music industry.

\section{Discussion}

\subsection{Discourse Coalitions and Regulatory Propaganda at Industry Events}

Our findings revealed two clearly identifiable discourse coalitions with respect to copyright regulation: conservatives on the one side aiming to preserve, strengthen, and better enforce existing copyright, and reformists on the other side, arguing for a copyright reform that takes into account new Internet user practices such as filesharing. Behind the conservative coalition are industry incumbents that cling to the traditional dominant logic [9] of music as a 
commodity: trade associations, collecting societies, labels, some artists, and the Popkomm as the incumbent industry event. In the reformist coalition, we find mainly actors from outside of the traditional music industry value chain, embracing two different avenues of business model innovation: music as a service or promotion tool, and music as a public good. Whereas the former is propagated mainly by corporate officials from related industries such as communications service providers or the gaming industry, the latter model is advocated by political actors such as digital rights NGOs, actors from the open source scene such as the all2gethernow organizers, and Pirate Party representatives.

What allows these two different actor groups to form a reformist discourse coalition in the sense of Hajer [36] is that both agree about repudiating overly restrictive enforcement measures. While their motives - profit with web-based services on the one hand, free speech and open access to digital goods on the other - may be different, their claims are compatible. This is in line with Hajer's [36] notion of a discursive affinity of certain arguments that do not necessarily require the sharing of deep values or a deliberate orchestration of activities. We also find some actors at the fringes of the two dominant discourse coalitions, some of which position themselves deliberately as outside of copyright disputes. The Reeperbahn Festival/Campus organizers, for instance, are the weakest actor group in our sample. This is because the Reeperbahn Festival stands for live music, a business model that has always been successful in the music industry and that remains untouched - or even silently profits - from regulatory uncertainty. Authors and artists are only weakly conservative, because they are engaged in a somewhat separate discourse - on the role and practices of collecting societies. Thus there is a little discursive affinity between these groups and the reformist discourse coalition.

Interestingly, the reformist and the conservative coalitions only rarely criticize each other, but instead address third parties [16] with their claims, especially the national legislature (with 
diverging regulatory demands), and the wider public (with moral pleas and oppositional story lines). Because of this discursive pattern, we prefer to speak of "regulatory propaganda" rather than regulatory conversations [10], as industry events are not used to engage in a dialogue and work towards reducing regulatory uncertainty, but rather to mobilize support for particular positions [73]. One explanation for this finding may lie in the fact that the events in our sample do not have a regulatory mandate and are not explicitly organized to develop new regulatory structures, unlike the United Nations [39] or technology [33] conferences. Instead, the events were organized by actors aiming to take part in regulatory debate or profit from regulatory uncertainty. Event organizers are hereby not only facilitators or arbiters, but selfinterested actors "with an eye towards influencing field evolution" [53], who position their events in the midst of public debates in a competition for audiences and media attention [74].

The increasing number of events may be seen as a by-product of regulatory uncertainty: uncertainty creates the need for sensemaking and coping, and discursive interaction facilitated by events is one way of achieving both. Uncertainty thus provides opportunities for lobbyists, entrepreneurs, or activists to open up and occupy new discursive spaces. The foundation of a new event, the all2gethernow, for instance, bundled the claims of dispersed reformist actors and has helped to bring reformist issues such as alternative licensing [21], the introduction of a flatrate fee for music and culture, or the reform of collecting societies onto the public agenda. In turn, the cancellation of a central event, in our case the Popkomm, was a powerful discursive strategy to transport the claims made by the conservative coalition, because all event-related reporting in the year of the cancellation made references to the industry crisis allegedly caused by illegal downloading. At the same time, the Popkomm cancellation opened a void that challenging actors could step into and open up a new discourse around music as a public good. As a potentially unintended side effect, the absence of a strong industry platform left the major and indie labels, as well as incumbent technology firms such as Microsoft or 
Apple relatively silent in the media debate, and tended to allow societal actors to propose their own vision of the industry's future business model. This notion of event foundation and cancellation as a discursive strategy presents an important addition to the recent literature on discourse and FCEs [39,92]. Specifically, our re-conceptualization of FCEs not only as discursive spaces providing a stage for third parties but, at the same time, as discursive artifacts themselves could be analyzed in other contexts.

\subsection{Cycles of Regulatory Propaganda and Business Model Innovation}

Taking industry events as sites for studying regulatory conversations in a field not only allowed us to track actors and claims, but also to observe discursive dynamics over a longer period of time. Our study is unique in that it illustrates which actor groups in a transforming field develop and maintain certain positions over time. In the case of the music industry, a dominant position based on past successful business models persisted among the core music industry actors throughout the ten-year period. While these actors lobbied for regulatory changes to preserve the old business model, new business models were mainly introduced by actors complementary to the traditional value chain or by societal actors. These actors are either not directly affected by copyright or would benefit from its abandonment, so they are not locked in by existing business models [17] and can more easily imagine alternatives under new regulatory structures.

Interestingly, the intensity of discourse varied as the perceived need for regulatory changes in the light of new business models changed and a clear address for claims existed. In the first (2001-2003) and in the third phases (2008-2010), industry actors sought government protection, initially by anti-circumvention provisions to protect private DRM standards and then, after the failure of DRM, by regulating Internet technologies more generally. These efforts were met in each phase by a rising number of reformist claims, introduced largely by new actors entering the field. This points to an overall cyclical nature of regulatory 
propaganda, where regulatory uncertainty returns as actors fail to innovate in the realm of existing regulatory settings. These cycles of high and low levels of regulatory discourse are not to be confused with phases of technological or industry life cycles (e.g. $[48,85])$, but instead resemble the ups and downs of business cycles. Their dynamics and outcomes may, however, be one factor that drives the transition from one stage in an industry or technological life cycle to the next.

At least in public, the music industry in our case maintained strong conservative positions when uncertainty was high, although the radical changes in positions found between active and past major label managers indicate that awareness of the need to innovate clearly existed. While in individual cases we did observe changes in positions over time, we cannot report similar findings on all individual actors that were quoted in our study, because our analysis was not fine-grained enough. Our general impression is, however, that organizational actors largely maintained their positions over the ten-year-period. This stability of actor positioning is also evidenced by the fact that new business model conceptions, such as the public goods model introduced at the end of the second period (2004-2007), were propagated by new actors (e.g. Pirate Party members). Established actors, be they conservative or reformist, mainly rephrased and re-emphasized their claims for the commodity and the service or promotion model respectively when discourse intensity rose again in period three (2008-2010).

Compared to their industry associations, the major and indie labels in our sample were only moderately conservative. This finding points to an interesting division of labor within the group of incumbent actors, which may also inform research on organizational field transformation (e.g. [42]). As private actors, it seems that the labels want to present themselves as innovative and successful enterprises and therefore deny that there is an industry crisis. Instead, they stress possibilities for business model innovation, including DRM, but also their new role as service providers for artists. Conservative claim making is 
left to the trade associations, meta-organizations [1] that seem to utilize events strongly as discursive spaces.

Surprisingly, we did not find any claim on the transnational nature of copyright regulation in the Internet age. This emphasizes, first, the importance of national regulatory discourse even in globalized industries such as the music industry. Second, it points to the need for research on regulatory struggles not only on the transnational, but also on national levels, even in fields with strong transnational regulation such as the field of copyright [21].

Generally, our findings strongly support the role of regulatory struggles in mediating the link between disruptive technologies and business model innovation. Similar to the pharma industry [75], technological discontinuities per se did not trigger a shift in the dominant industry logic. Instead, the most radical impulses for change in our study stemmed from a growing political and societal movement towards making copyright less relevant in the production of cultural goods [22] - a shift comparable to new healthcare philosophies - and actors entering from other industries. These actors do not benefit from extant regulation and embrace regulatory uncertainty as an opportunity to develop and propose new business models. Those already practicing new business models, the majority of musicians and artists, remained largely absent from the regulatory debate.

Finally, the findings of this study seem to be most relevant for research on other cultural industries such as the film or the publishing industry, which are also copyright-based (e.g. [61]). With growing proliferation of broadband Internet access and of new devices such as smartphones or tablet PCs, these industries are likely to experience similar cycles of regulatory uncertainty with recurrent windows of opportunity for business model innovation. In particular, the change in consumer practices and according demands for regulatory changes that we observed in the music industry play a similar role in these markets, and incumbent organizations have been found to be similarly locked-in to past business models (e.g. $[49,50]$ 
for newspaper publishing). However, both regulatory and technological peculiarities of these markets, such as fixed book prices or bandwidth management by Internet service providers, may also complicate the transfer of our results. 


\section{Conclusions, Outlook and Implications for Management Practice}

Quite in contrast to the proposed crisis of the music industry, we can see a thriving event landscape. At least some of the newly founded events are social-movement like organizations seeking to open up the debate on copyright and to find new solutions and business models. Perhaps not in terms of financial revenues, but in terms of activism, debate, and exchange of ideas, the music industry appears lively. If this can be taken in any way as an indication, then we do not see a cultural decline caused by digital technology, but a challenging debate and a diverse set of practices regarding the use of music in modern cultural production.

Building upon our findings, further research could examine whether different kinds of events facilitate different discursive patterns, depending on their mandate, their organizers, and their position in an organizational field. The role of the (non-neutral) arbiter that brings together these separate coalitions is rather taken up by the media, itself veering towards reformist positions. It would be interesting to compare what is actually said at events with the way it is represented by the media in order to enhance our understanding of the role of the media as a non-neutral arbiter and hence as an active member of discourse coalitions.

In this context, studying the discursive strategies of different actors at different points in time within different discursive spaces would help to provide a more in-depth understanding of how incumbent-challenger dynamics play out in a transforming industry field. For instance, while organizing and cancelling events was an effective strategy used by both conservative and reformist actors aiming to mobilize support for certain positions, these strategies are likely to be complemented by direct lobbying efforts or other political activities, such as engaging in transnational regulatory arenas.

Since our analysis was focused on Germany, further research could also systematically compare the shape of the evolving event landscapes and discourse coalitions in other 
countries to see if similar themes or phases can be identified and whether the cyclical dynamic of regulatory debate can be confirmed. Our findings provide a first step towards more nation-based regulation studies, and we hope to have inspired research in this direction.

Complementary research on different national regulatory processes, comparing regulatory propaganda across different cultural industries, would help to clarify whether we can see convergence in terms of discourse and business model approaches or whether differences, for example with regard to Digital Rights Management [27], still persist. These findings could then inform further research on why industry incumbents often fail to envision new forms of value proposition and value capture in the Internet age [87]. Specifically, the complementary interplay of cycles of regulatory uncertainty and propaganda described in this study and the cyclical nature of technological uncertainty $[75,70]$ deserve closer investigation.

For managers maneuvering businesses through periods of industry transformation, our analysis of regulatory propaganda in the music industry may be informative in at least three respects. First, business model innovation is likely to come from the fringes or even from actors external to the field. Under regulatory uncertainty, these are potential partners for strategic alliances to explore alternative avenues for industry development. Second, not only discourse at existing industry events but also the foundation of new and seemingly less central industry events may have a strong impact on how regulatory discourse unfolds - not least because new events are newsworthy just in themselves and their organizers have an eye towards field evolution. Attending these events may be an important source of fresh ideas for proactively addressing regulatory uncertainty. Third, the intensity of discourse on business model innovation and complementary regulation is likely to be cyclical in nature, depending on the perceived acuteness of an industry crisis. Consequently, industry crisis rather than mere technological developments opens up discursive spaces for introducing new or alternative business models. While departing further from established paths with new 
business models may be particularly promising in times of crisis, therefore, this also suggests making counter-cyclical investments in business model exploration as a strategy for generating competitive advantages in the medium- and long-run.

\section{References}

[1] G. Ahrne, N. Brunsson, Meta-organizations, Cheltenham: Edward Elgar (2008).

[2] N. Anand, R.A. Peterson, When market information constitutes fields: Sensemaking of markets in the commercial music industry, Organization Science, 11(3) (2000) 270-284.

[3] N. Anand, M.R. Watson, Tournament Rituals in the Evolution of Fields: The Case of Grammy Awards, Academy of Management Journal, 47 (1) (2004) 59-80.

[4] B. Andersen, R. Kozul-Wright, Z. Kozul-Wright, Rents, Rights N'Rhythm: Cooperation, Conflict and Capabilities in the Music Industry, Industry \& Innovation, 14(5) (2007) 513-540.

[5] R.U. Ayres, E. Williams, The digital economy: Where do we stand? Technological Forecasting and Social Change, 71(4) (2004) 315-339.

[6] D. Bach, The Double Punch of Law and Technology: Fighting Music Piracy or Remaking Copyright in a Digital Age? Business and Politics, 6 (2) (2004) 1-33.

[7] E. Becker, W. Buhse, D. Günnewig, N. Rump, Digital Rights Management: Technological, Economic, Legal and Political Aspects. Berlin: Springer (eds./2003).

[8] G. Bentrup, Evaluation of a collaborative model: A case study of analysis of watershed planning in the Intermountain West, Environmental Management, 27 (2001) 739-48.

[9] R.A. Bettis, C.K. Prahalad, The Dominant Logic: Retrospective and Extension, Strategic Management Journal, 16 (1996) 5-14.

[10] J. Black, Regulatory Conversations, Journal of Law and Society, 29 (1) (2002) 163-196.

[12] L.J. Bourgeois, Strategic goals, perceived uncertainty, and economic performance in volatile environments, Academy of Management Journal, 28(3) (1985) 548-573.

[13] J. Braithwaite, P. Drahos, Global Business Regulation, Cambridge: Cambridge University Press (2000).

[14] J. Braithwaite, Rules and Principles: A Theory of Legal Certainty, Australian Journal of Legal Philosophy, 27 (2002) 47-82.

[15] N. Brunsson, The Organization of Hypocrisy, Talk, decisions and actions in organizations, Chichester: Wiley (1989).

[16] N. Brunsson, B. Jacobsson, A world of standards, Oxford: Oxford University Press (2000). 
[17] R.A. Burgelman, Strategy as vector and the inertia of coevolutionary lock-in, Administrative Science Quarterly, 47 (2002) 325-357.

[18] S. Casper, Institutional adaptiveness, technology policy, and the diffusion of new business models: the case of German biotechnology, Organization Studies, 21 (2000) 887-914.

[19] H. Chesbrough, Business model innovation: Opportunities and barriers, Long Range Planning 43 (2010) 354-363.

[20] F. Dobbin, T.J. Dowd, How Policy Shapes Competition: Early Railroad Foundings in Massachusetts. Administrative Science Quarterly, 42 (1997) 501-529.

[21] L. Dobusch, S. Quack, Epistemic Communities and Social Movements: Transnational Dynamics in the Case of Creative Commons. In Djelic, M-L. \& Quack, S. eds.), Transnational Communities: Shaping Global Economic Governance, Cambridge: Cambridge University Press (2010) 226-251.

[22] L. Dobusch, S. Quack, Framing standards, mobilizing users: Copyright versus fair use in transnational regulation, Review of International Political Economy, in press (2012).

[23] U. Dolata, Technological innovations and sectoral change, Transformative capacity, adaptability, patterns of change: An analytical framework, Research Policy, 38(6) (2009) 1066-1076.

[24] U. Dolata, The Music Industry and the Internet: A Decade of Disruptive and Uncontrolled Sectoral Change, SOI Discussion Paper 2011-02, Online: http://www.unistuttgart.de/soz/oi/publikationen/soi2_dolata_music_industry.pdf (2011).

[25] P. Drahos, J. Braithwhite, Information Feudalism: Who Owns the Knowledge Economy? London: Earthscan (2002).

[26] C. Engau, V. Hoffmann, Corporate response strategies to regulatory uncertainty: vidence from uncertainty about post-Kyoto regulation, Policy Sciences, 44(1) (2011) 53-80.

[27] M. Fetscherin, M. Schmid, Comparing the usage of digital rights management systems in the music, film, and print industry, Proceedings of the 5th international conference on Electronic commerce (2003) $316-325$.

[28] M. Fink, R. Lang, R. Harms, Local responses to global technological change - Contrasting restructuring practices in two rural communities in Austria. Technological Forecasting and Social Change (2003) in print.

[29] N. Fligstein, Markets as politics: A political-cultural approach to market institutions, American Sociological Review, 61(4) (1996) 656-673.

[30] A. Fremeth, B. Richter, Staying Ahead of and Profiting from Environmental Regulatory Uncertainty: Integrated Strategies for Competitive Advantage, Available at SSRN: http://ssrn.com/abstract=1905789 (2011).

[31] P. Galuszka, Netlabels and democratization of the recording industry, First Monday, 7 (7), Online: ttp://firstmonday.org/htbin/cgiwrap/bin/ojs/index.php/fm/article/view/3770/3278 [July 14, 012] (2012). 
[32] A. Gambardella, A.M. McGahan, Business-Model Innovation: General Purpose Technologies and their Implications for Industry Structure, Long Range Planning, 43 (2/3) (2010) 62-271.

[33] R. Garud, Conferences as venues for the configuration of emerging organizational fields: The case of cochlear implants, Journal of Management Studies, 45(6) (2008) 1061-1088.

[34] A. Giddens, The Constitution of Society, Outline of the Theory of Structuration, Berkeley: University of California Press (1984).

[35] M. Green, Napster Opens Pandora's Box: Examining How File-Sharing Services Threaten the Enforcement of Copyright on the Internet, Ohio Law Journal, 63 (2002) 799-818.

[36] M.A. Hajer, Discourse Coalitions and the Institutionalization of Practice: The Case of Acid Rain in Britain, In: F.Fischer, J.Forester (eds.): The Argumentative Turn in Policy Analysis and Planning. Durham and London: Duke University Press (1993) 43-76.

[37] M.A. Hajer, Coalitions, Practices, and Meaning in Environmental Politics: From Acid Rain to BSE. In: D.Howarth, J.Torfing (eds.): Discourse Theory in European Politics: Identity, Policy and Governance, Houndmills: Palgrave Macmillan (2005) 297-315.

[38] C. Hardy, S. Maguire, Institutional entrepreneurship, In R.Greenwood, C.Oliver, K.Sahlin, R.Suddaby (eds.) The Sage Handbook of Organizational Institutionalism, Sage Publications (2008) 198-217.

[39] C. Hardy, S. Maguire, Discourse, field-configuring events, and change in organizations and institutional fields: Narratives of DDT and the Stockholm Convention, Academy of Management Journal, 53(6) (2010) 1365-1392.

[40] S. Haunss, L. Kohlmorgen, Lobbying or Politics? Political Claims Making in IP Conflicts. In: S.Haunss, K.C.Shadlen (eds.): Politics of Intellectual Property, Contestation over the Ownership, Use, and Control of Knowledge and Information, Cheltenham (2010) 107-127.

[41] L.R. Helfer, Regime Shifting: The TRIPs Agreement and New Dynamics of International Intellectual Property Lawmaking, Yale Journal of International Law, 29 (2004) 1-81.

[42] M. Hensmans, Social movement organizations: A metaphor for strategic actors in institutional fields, Organization Studies, 24(3) (2003) 355-381.

[43] A.J. Hoffman, Institutional Evolution and Change: Environmentalism and the U.S. Chemical Industry, In: Academy of Management Journal, 42 (4) (1999) 351-371.

[44] V.H. Hoffmann, T. Trautmann, J. Hamprecht, Regulatory uncertainty - a reason to postpone investments? Not necessarily. Journal of Management Studies 46(7) (2009) 227-1253.

[45] V.H. Hoffmann, T. Trautmann, M. Schneider, A taxonomy for regulatory uncertainty application to the European emission trading scheme, Environmental Science \& Policy, 11(8) (2008) 712-722.

[46] M. Huygens, C. Baden-Fuller, F.A.J. Van Den Bosch, H.W. Volberda, Co-evolution of firm capabilities and industry competition: Investigating the music industry, 1877-1997, Organization Studies, 22/6 (2001) 971-1011. 
[47] L.K. Jauch, K.L. Kraft, Strategic Management of Uncertainty, Academy of Management Review, 11 (4) (1986) 777-790.

[48] S. Klepper, Industry Life Cycles, Industrial \& Corporate Change, 6 (1997) 119-143.

[49] J. Koch, Strategic paths and media management - A path dependency analysis of the German newspaper branch of high quality journalism, Schmalenbach Business Review, 60 (2008) 5073.

[50] J. Koch, Inscribed Strategies: Exploring the Organizational Nature of Strategic Lock-in, in: Organization Studies 32 (3) (2011) 337-363.

[51] M. Kretschmer, Policy Review: Trends in Global Copyright, Global Media and Communication, 1 (2) (2005) 233-239.

[52] R.W. Künneke, Institutional reform and technological practice: The case of electricity, Industrial and Corporate Change, 17 (2) (2008) 233-265.

[53] J. Lampel, A.D. Meyer, Field-Configuring Events as Structuring Mechanisms: How Conferences, Ceremonies, and Trade Shows Constitute New Technologies, Industries, and Markets, Journal of Management Studies, 45 (6) (2008) 1025-1035.

[54] S. Larsson, The Path Dependence of European Copyright, SCRIPT-ed, 8 (1) (2011) 8-31.

[55] T.B. Lawrence, R. Suddaby, B. Leca (eds.), Institutional Work and the Paradox of Embedded Agency, Cambridge, UK: Cambridge University Press (2009).

[56] L. Lessig, Free Culture: How Big Media Uses Technology and the Law to Lock Down Culture and Control Creativity, New York: Penguin Press (2004).

[57] S.J. Liebowitz, File Sharing: Creative Destruction or Just Plain Destruction? The Journal of Law and Economics, 49 (1) (2006) 1-28.

[58] B.J. Loasby, Capabilities and strategy: problems and prospects, Industrial and Corporate Change, 19 (4) (2010) 1301-1316.

[59] P. McInerney, Showdown at Kykuit: Field-configuring events as loci for conventionalizing accounts. Journal of Management Studies, 45(6) (2008) 1089-1116.

[60] I.S.M. Meijer, M.P. Hekkert, J.F.M. Koppenjan, How perceived uncertainties influence transitions; the case of micro-CHP in the Netherlands, Technological Forecasting and Social Change, 74 (4) (2007) 519-537.

[61] J.B. Meisel, T.S. Sullivan, The impact of the Internet on the law and economics of the music industry, Info, 4 (2) (2002) 16-22.

[62] A.D. Meyer, V. Gaba, K.A. Colwell, Organizing far from equilibrium: Nonlinear change in organizational fields, Organization Science, 16 (5) (2005) 456-473.

[63] B. Moeran, J. Strandgaard Pedersen, Introduction, In B. Moeran and J. Strandgaard Pedersen (Eds.), Negotiating Values in the Creative Industries: Fairs, Festivals and Competitive Events: 1-35, Cambridge: Cambridge University Press (2011). 
[64] L. Molteni, A. Ordanini, Consumption Patterns, Digital Technology and Music Downloading, Long Range Planning 36 (4) (2003) 389.

[65] K.A. Munir, N. Phillips, The birth of the 'Kodak moment': institutional entrepreneurship and the adoption of new technologies, Organization Studies, 26 (2005) 1665-1687.

[66] R.L. Okediji, The regulation of creativity under the WIPO Internet Treaties, Fordham Law Review, 77 (2009) 2379-2410.

[67] A.L. Oliver, K. Montgomery, Using Field-Configuring Events for Sense-Making: A Cognitive Network Approach, Journal of Management Studies, 45 (6) (2008) 1147-1167.

[68] A. Ordanini, G. Rubera, M. Sala, Integrating functional knowledge and embedding learning in new product launches: How project forms helped EMI music, Long Range Planning, 41 (2008) 17-32.

[69] M. Paiola, Cultural Events as Potential Drivers of Urban Regeneration: An Empirical llustration, Industry \& Innovation 15(5) (2008) 513-529.

[70] R. Phaal, E. O’Sullivan, M. Routley, S. Ford, D. Probert, A framework for mapping industrial emergence, Technological Forecasting \& Social Change, 78 (2011), 217-230.

[71] P.W.B. Philips, W.A. Kerr, Frustrating Competition Through Regulatory Uncertainty, World Competition, 25 (1) (2002) 81-99.

[72] S. Quack, Legal Professionals and Transnational Law-Making: A Case of Distributed Agency, Organization, 14 (5) (2007) 643-666.

[73] H. Rao, Market Rebels: How Activists Make Or Break Radical Innovations, New Jersey: Princeton University Press (2009).

[74] C.-C. Rüling, J. Strandgaard Pedersen, Film festival research from an organizational studies perspective. Scandinavian Journal of Management, 26 (2010) 318-323.

[75] V. Sabatier, A.Craig-Kennard, V.Mangematin, When technological discontinuities and disruptive business models challenge dominant industry logics: Insights from the drugs industry, Technological Forecasting and Social Change 79 (2012) 949-962.

[76] L.-M. Sainio, K. Puumalainen, Evaluating technology disruptiveness in a strategic corporate context: A case study, Technological Forecasting and Social Change 74 (2007) 1315-1333.

[77] M. Schneider, J. Scholz, M. Lubell, D. Mindruta, M. Edwardsen, Building consensual institutions: Networks and the national estuary program, American Journal of Political Science, 47 (2003) 143-58.

[78] S.E. Siwek, Copyright Industries in the U.S. Economic: The 2006 Report, Prepared for the International Intellectual Property Alliance (2006). Online:

http://www.iipa.com/pdf/2006_siwek_full.pdf [accessed: 10 March 2009]

[79] M. Stefik, DRM Inside: DRM and the Future of Digital Media, Working Paper (2007). Online: http://www.parc.com/research/publications/details.php?id=6250; 30.08.2008. 
[80] R. Suddaby, R. Greenwood, Rhetorical strategies of legitimacy, Administrative Science Quarterly, 50 (2005) 35-67.

[81] D.J. Teece, Business Models, Business Strategy and Innovation, Long Range Planning, 43(2/3) (2010) 172-194.

[82] C. Topal, The Construction of General Public Interest: Risk, Legitimacy, and Power in a Public Hearing, Organization Studies, 30 (2-3) (2009) 277-300.

[83] P. Tschmuck, Creativity and Innovation in the Music Industry, Dordrecht, Springer (2006).

[84] M.L. Tushman, L. Rosenkopf, Organizational Determinants of Technological Change: Toward a Sociology of Technological Evolution, Research in Organizational Behavior, 14, (1992), 311-347.

[85] J.M. Utterback, W.J. Abernathy, A dynamic model of process and product innovation, Omega 3 (6) (1975) 639-656.

[86] J.B. Wade, A. Swaminathan, M.S. Saxon, Normative and Resource Flow Consequences of Local Regulations in the American Brewing Industry, 1845-1918, Administrative Science Quarterly, 43 (4) (1998), 905-935.

[87] B.W. Wirtz, O. Schilke, S. Ullrich, Strategic Development of Business Models, Implications of the Web 2.0 for Creating Value on the Internet, Long Range Planning, 43 (2010) 272-290.

[88] T. Wu, The Master Switch: The Rise and Fall of Information Empires. New York: Knopf (2010).

[89] R.K. Yin, Case Study Research (4th ed.) Sage: Thousand Oaks (2009).

[90] M. Yunus, B.Moingeon, L.Lehmann-Ortega, Building social business models: Lessons from the Grameen experience, Long Range Planning 43 (2010) 308-325.

[91] A. Zentner, Ten Years of File Sharing and Its Effect on International Physical and Digital Music Sales. Working Paper (2010). Online: http://ssrn.com/abstract=1724444 [accessed: 14 July 2012]

[92] T.B. Zilber, Institutional Multiplicity in Practice: A Tale of Two High-Tech Conferences in Israel, Organization Science, 22(6) (2011) 1539-1559.

[93] C. Zott, R. Amit, Business Model Design: An Activity System Perspective. Long Range Planning, 43 (2/3) (2010) 216-226. 


\section{Appendix}

\begin{tabular}{lc}
\hline Conservative (13 claims) & Frequency \\
\hline Internet file sharing causes crisis. & 63 \\
Government needs to act (enforce copyright, protect industry, regulate & \\
internet). (COM) & 40 \\
DRM is the solution. (COM) & 21 \\
Artists need to be remunerated/respect artists' rights. & 16 \\
Internet filesharing is stealing. (COM) & 10 \\
Copyright enforcement works. (COM) & 7 \\
Flatrate won't work/is the new broadcast fee. & 6 \\
Legal basis of copyright needs to be accepted. (COM) & 6 \\
Pirate Party only wants votes/is not serious. & 6 \\
Creative Commons does not work. (COM) & 4 \\
New business models don't work. (COM) & 4 \\
Cultural variety/quality will die along with employment. & 3 \\
GEMA-flatrate/GEMA works. & 3 \\
\hline Total (conservative) & 189
\end{tabular}

\section{Reformist (15 claims)}

New business models are emerging. (SPM) 29

Music industry failed to innovate/is outdated. 25

DRM does not work. $\quad 24$

$\begin{array}{ll}\text { Industry needs to and can change/innovate. (SPM) } & 19\end{array}$

$\begin{array}{ll}\text { Internet filesharing (alone) is not the problem. } & 11\end{array}$

$\begin{array}{ll}\text { Criminalization strategy will not work. } & 10\end{array}$

$\begin{array}{ll}\text { Industry criminalizes fans. } & 10\end{array}$

Copyright is anachronistic/instrumentalized by industry. (PGM) 9

$\begin{array}{ll}\text { Internet filesharing should be legalized. } & 7\end{array}$

GEMA distribution of royalties too complicated. $\quad 6$

Flatrate as an option. (PGM) $\quad 5$

Internet should not be regulated. (PGM) 5

Need to include consumers, other industries in debate. (SPM) 4

Open content licences as an option. (PGM) 4

\begin{tabular}{lc} 
Artists need to take new roles (e.g. self-publishers). & 2 \\
\hline Total (reformist) & 170
\end{tabular}

\section{Other (6 claims)}

GEMA does not protect artists. 6

There is no crisis. $\quad 6$

Moral issue turned into a legal/business issue. $\quad 4$

New generation is a pirate generation. $\quad 4$

Musicians always had to struggle. 1

We have never paid for the music. 1

\begin{tabular}{lc}
\hline Total (other) & 22 \\
\hline Total (overall) & $\mathbf{3 8 1}$
\end{tabular}

Table A.1: Grouped claims and frequencies 


\begin{tabular}{cccc}
\hline Event & Location & Founding & End \\
\hline Munich Mobile Music Conference & Munich & 2004 & 2005 \\
Hamburger Musikforum/VUT-Nord Stammtisch & Hamburg & 2004 & - \\
Popkomm & Düsseldorf/Cologne/Berlin & 1989 & 2012 \\
all2gethernow & Berlin & 2009 & - \\
Future Music Camp & Mannheim & 2009 & - \\
CeBit Sounds! & Hannover & 2010 & - \\
c/o pop/C'n'B & Cologne & 2004 & - \\
DJ Meeting & Oberhausen & 1990 & - \\
filmtonart - Tag der Filmmusik & Munich & 2009 & - \\
forward2business-Zukunftskongress & Halle (Saale) & 2002 & - \\
Green Music Initiative Roundtable & Berlin & 2009 & - \\
jazzahead! & Bremen & 2006 & - \\
Kinderlied-Kongress & Hamburg & 2007 & - \\
Jetztmusikfestival 2010/Time Warp & Mannheim & 2007 & - \\
MusicCity Hamburg & Hamburg & 1997 & - \\
Musik und Maschine & Berlin & 2000 & 2003 \\
Popmeeting Niedersachsen & Berlin & 2002 & 2008 \\
Pop-Open Stuttgart & Leipzig & 2007 & -
\end{tabular}

Table A.2: Event landscape in the German music industry 


\begin{tabular}{|c|c|c|}
\hline Story line & $\begin{array}{c}\text { Period I: } \\
\text { 2001-2003 }\end{array}$ & $\begin{array}{l}\text { Period II: } \\
\text { 2004-2007 }\end{array}$ \\
\hline $\begin{array}{l}\text { Music as a } \\
\text { commodity }\end{array}$ & $\begin{array}{l}29 \text { claims } \\
\text { "New music CDs will only } \\
\text { be available with copy } \\
\text { protection. This is how } \\
\text { labels want to stop illegal } \\
\text { burning of CDs." (SZ, } \\
\text { 2001) } \\
\text { "That circumvention of copy } \\
\text { protection will be legally } \\
\text { banned in Germany is } \\
\text { considered to be a } \\
\text { success." (FAZ, 2002) } \\
\text { "The music firms demand } \\
\text { authoritative actions of the } \\
\text { legislation against illegal } \\
\text { copying." (SZ, 2002) }\end{array}$ & $\begin{array}{l}19 \text { claims } \\
\text { "Corporations such as the } \\
\text { Swiss SDC AGG } \\
\text { presented DRM software } \\
\text { to be used in online or } \\
\text { mobile record stores such } \\
\text { as iTunes (Apple) or } \\
\text { Musicload (T-Online)." } \\
\text { (RP, 2005) } \\
\text { "Without DRM nothing goes } \\
\text { at the industry's top dogs" } \\
\text { (MW, 2006) } \\
\text { "Actually, the state would } \\
\text { need to act here (...)." } \\
\text { (SZ, 2007) }\end{array}$ \\
\hline
\end{tabular}

\begin{tabular}{ll}
\hline Music as a & 18 claims \\
service or & "The view that the sound \\
promotion tool & carrier CD is a phase-out \\
& model is common wisdom. \\
& The ideal customer [...] is \\
& automatically charged for \\
& his pre-paid music \\
& subscription." (FAZ, \\
& 2001) \\
"To go against [illegal & copying], the German \\
& music industry is going to \\
& launch a central supplier \\
& for legally downloading \\
& songs from the Internet." \\
(HA, 2003) & "Microsoft will forestall \\
& competitor Apple with his \\
& new offers in Europe \\
& (...)." (FAZ, 2003)
\end{tabular}

\begin{tabular}{ll} 
& phone users." (BZ, 2007) \\
\hline Music as a & no claims \\
public good & "Rights holders should work \\
& with alternative licensing \\
& models, otherwise \\
creativity and cultural & diversity will be stifled." \\
& (MW, 2007 \\
"A definitive yes to a clearly \\
defined cultural flatrate." \\
(MW, 2007)
\end{tabular}

\section{4 claims
"Music is used as a free} supplement and promotion gift, to sell detergent or hardware." (FAZ, 2004)

"New distribution and marketing channels are emerging: many newcomers such as the Arctic Monkeys became prominent via blogs." (BZ, 2006)

"The music business on the Internet is booming in Germany as never before." (HA, 2006)

"The music streaming service mSpot/Remix was developed to deliver music to two billion mobile phone users." (BZ, 2007)

"Rights holders should work with alternative licensing models, otherwise creativity and cultural diversity will be stifled." (MW, 2007

defined cultural flatrate." (MW, 2007)

Period III:
2008-2010

41 claims

"There is no way around regulating the Internet." (MW, 2008)

"Gorny blamed 'inaction of politicians' for cancelling the Popkomm." (FAZ, 2009)

We ought not to sacrifice copyright on the altar of digital coolness." (MW, 2009)

"It is a scandal that many authors go away emptyhanded from new Internet business models. Such an expropriation is not acceptable." (MW, 2009)

\section{0 claims}

"Old discussions on the chances and risks of YouTube and MySpace are continued, music-ondemand is being refined." (FAZ, 2008)

"Selling music via the Internet only works in connection with other business models - it is the cookie served with the coffee." (MW, 2008)

"The industry has done its homework and confronts the technological change with digital offers." (MM, 2009)

21 claims

"The most promising models are still flatrate models that allow the continued possession of music." (SZ, 2009)

"Creative Commons licenses were discussed.” (MM, 2009)

"The Pirate Party is the figurehead of the movement, whose activists consider any intervention into the Internet as a mutilation of basic civil liberties." (BZ, 2009)

"[N]owadays, composing a truly 'new' song is impossible and thus copyright and GEMA are 
Legend: BZ = Berliner Zeitung, FAZ = Frankfurter Allgemeine Zeitung, HA = Hamburger Abendblatt, MM = Musikmarkt, $\mathrm{MW}=$ Musikwoche, $\mathrm{RP}=$ Rheinische Post, $\mathrm{SZ}=$ Süddeutsche Zeitung

Table A.3: Coding examples of dominant claims in different phases

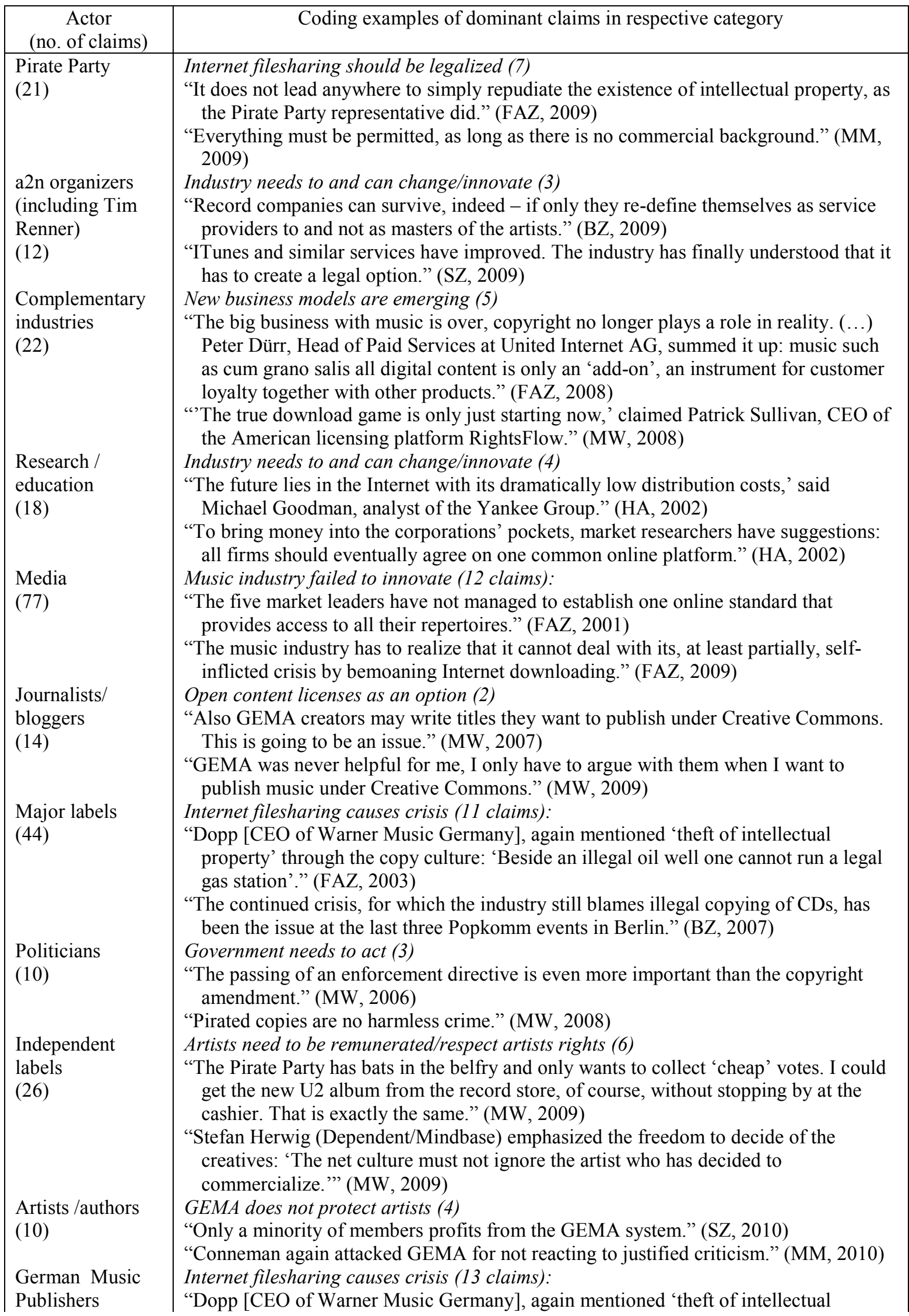


Association

(32)

GEMA

/collecting

societies

(13)

Dieter Gorny

(51) property' through the copy culture: 'Beside an illegal oil well one cannot run a legal gas station'." (FAZ, 2003)

"The continued crisis, for which the industry still blames illegal copying of CDs, has been the issue at the last three Popkomm events in Berlin." (BZ, 2007)

Government needs to act (4)

"The GEMA critically emphasizes that anyone who downloads music from the Internet violates copyrights." (SZ, 2005)

"It is a scandal that rights holders do not profit from the variety of new online business models." (MW, 2009)

Internet filesharing causes crisis (20 claims):

"Many firms cannot afford to participate at the Popkomm because of the theft on the Internet" (BZ, 2009)

"If there is no action soon, all efforts of the industry will be futile." (MM, 2009)

Legend: BZ = Berliner Zeitung, FAZ = Frankfurter Allgemeine Zeitung, HA = Hamburger Abendblatt, MM

$=$ Musikmarkt, MW = Musikwoche, $\mathrm{RP}=$ Rheinische Post, $\mathrm{SZ}=$ Süddeutsche Zeitung

Table A.4: Coding examples of dominant claims per actor group (actors with $>4$ claims) in the order of the reformist-conservative scale (Figure 6) 